\title{
Implementasi Regulatory Impact Assessment (RIA) Sebagai Upaya Menjamin Partisipasi Masyarakat Dalam Penyusunan Peraturan Daerah
}

\author{
Nasokah \\ Partnership for Governance Reform in Indonesia, \\ Kantor Regional Yogyakarta. \\ e-mail : nasokah@yahoo.com
}

\begin{abstract}
Regulatory Impact Assessment (RIA) is independently institutionalized as a quality control for local ordinances, be it for the draft of such ordinances or for those which are the established ordinances. RIA guides the logics and reasons in legislation process of a regulation without altering the existing mechanisms and institutions related to the issuance of a regulation
\end{abstract}

Keywords: Regulatory Impact Assessment, Public's Participation, Local Ordi nance

\section{Pendahuluan}

Negara Kesatuan Republik Indonesia dibagi atas daerah-daerah propinsi, dan daerah propinsi itu dibagi atas kabupaten dan kota, yang tiap-tiap propinsi, kabupaten, dan kota itu mempunyai pemerintahan daerah, yang diatur dengan undang-undang. Begitulah bunyi Pasal 18 ayat (1) UUD 1945 Perubahan. ${ }^{1}$ Sebagai konsekuensi dari pembagian daerah dan pemberian kewenangan berupa otonomi daerah, maka setiap pemerintahan daerah berhak menetapkan peraturan daerah dan peraturan-peraturan lain untuk melaksanakan otonomi dan tugas pembantuan.

\footnotetext{
${ }^{1}$ Pasal 18 (1) Undang-Undang Dasar RI 1945.
} 
Undang-undang yang mengatur tentang pemerintahan daerah yang dimaksud oleh Pasal 18 ayat (1) tersebut adalah Undang-undang No. 32 Tahun 2004 yang tertuang dalam Lembaran Negara RI Tahun 2004 Nomor 125. Pemerintahan daerah dalam menyelenggarakan urusan pemerintahan yang menjadi wewenangnya yang diberikan oleh UUD 1945 (Pasal 18 ayat 6) dan juga UU tentang Pemerintahan Daerah tersebut, salah satunya adalah untuk membentuk peraturan daerah dan peraturan pelaksanaan lainnya.

Pemberian otonomi kepada daerah dan kewenangan dalam menetapkan peraturan daerah dimaksudkan sebagai upaya untuk memberikan keleluasaan kepada daerah sesuai dengan kondisi lokalistiknya. Selain itu juga dimaksudkan untuk mendekatkan jarak antara pembuat peraturan daerah (pejabat daerah) dengan rakyat di daerahnya sehingga terbangun suasana komunikaitif yang intensif dan harmonis diantara keduanya. Artinya keberadaan rakyat di daerah sebagai subjek pendukung utama demokrasi mendapat tempat dan saluran untuk berpartisipasi terhadap berbagai peraturan daerah yang dikeluarkan/ dihasilkan oleh pemerintahan daerah.

Kualitas peraturan daerah menjadi indikator penting kinerja tata pemerintahan di daerah. ${ }^{2}$ Kewenangan daerah yang semakin besar setelah otonomi daerah membuat pemerintah daerah memberlakukan berbagai peraturan daerah yang dibuat untuk mengatur kegiatan ekonomi dan sosial di daerahnya. Persoalan muncul ketika kebanyakan peraturan itu kemudian dinilai oleh pemangku kepentingan di daerah atapun di pusat tidak sesuai dengan tujuan pemberian otonomi itu sendiri. Otonomi daerah dilaksanakan karena pemerintah ingin mempercepat perbaikan kemakmuran masyarakat di daerah. Namun, sayangnya karena pertimbangan kepentingan sempit dan jangka pendek, justru peraturan yang dibuat oleh daerah kabupaten atau provinsi tidak mampu mendorong pembangunan yang berkelanjutan di daerah.

Terdapat beberapa persoalan ketika kebijakan otonomi daerah mulai diterapkan. ${ }^{3}$ Kapasitas DPRD dan pemerintah tingkat kabupaten dalam melaksanakan tanggungjawab baru dan menetapkan rencana

${ }^{2}$ Agus Dwijanto et. al, Kinerja Tata Pemerintahan di Indonesia, Yogyakarta: Pusat Studi Kependudukan dan Kebijakan Universitas Gajah Mada (PSKK UGM)Kemitraan, 2007, hlm. 10.

${ }^{3}$ Word Bak Institute, Perda Review Project, September, 2004, dalam http:/ / www.justiceforthepoor.or.id. 
pembangunan pemerintah di tingkat daerah secara menyeluruh untuk di setiap kabupaten masih dipertanyakan. Beberapa fakta yang diperoleh secara random/acak dan kajian yang dilakukan secara sederhana menunjukkan beberapa potensi persoalan yang timbul dalam kebijakan otonomi daerah: 1. Ketidakselarasan kebijakan peraturan daerah dengan peraturan daerah lainnya di tingkat lokal; 2. Ketidakselarasan kebijakan otonomi daerah dengan hukum nasional dan kewajiban internasional Indonesia atas hukum dan nilai-nilai Hak Asasi Manusia; 3. Praktekpraktek bisnis tertentu atau pemberian hak istimewa kepada perusahaan milik pemerintah daerah (BUMD); 4. Kegagalan untuk mensahkan atau mengimplementasikan peraturan daerah sebagaimana disyarakat oleh hukum nasional (contohnya: pengesahan Badan Perwakilan Desa yang terpilih secara demokratis);

Pada saat yang sama, ketiadaan analisa yang mendalam/komprehensif mengenai peraturan daerah akan membatasi peluang Pemerintah Daerah untuk belajar dari proses pembangunan yang positif dan inovatif di tingkat lokal sebagai dampak langsung dari kebijakan otonomi daerah. Singkatnya, sampai saat ini kita belum mengetahui secara lengkap mengenai performa kinerja pemerintah daerah yang sebenarnya memiliki dampak yang sangat besar terhadap kehidupan bangsa Indonesia sehari-hari.

Sesuai dengan prinsip demokrasi, dimana para wakil rakyat di daerah dan kepala daerah dipilih secara langsung oleh rakyat di daerah, diharapkan mereka senantiasa menjalin komunikasi dengan rakyat terkait dengan pembuatan dan penentuan kebijakan daerah yang dituangkan dalam peraturan daerah. Pemberian saluran dan ruang kepada masyarakat di daerah untuk berpartisipasi dalam proses pembuatan dan penentuan peraturan daerah merupakan amanat Undang-Undang Nomor 10/2004 tentang Pembentukan Peraturan Perundang-Undangan Pasal 53. ${ }^{4}$ Bunyi selengkapnya pasal tersebut: "Masyarakat berhak memberikan masukan secara lisan atau tertulis dalam rangka penetapan maupun pembahasan rancangan undang-undang dan rancangan peraturan daerah."

Hal ini juga ditegaskan dalam UU No. 32/2004 Pasal 139 ayat (1) bahwa masyarakat berhak memberikan masukan secara lisan atau tertulis dalam rangka penyiapan atau pembahasan rancangan Perda. ${ }^{5}$

${ }^{4}$ Pasal 53 UU No. 10/2004 tentang pembentukan Peraturan Perundangundangan.

${ }^{5}$ Pasal 139 ayat (1) UU No. 32/2004 Tentang Pemerintahan Daerah. 
Dari ketentuan dalam dua Pasal dua Undang-undang tersebut memberikan penyadaran kepada semua pihak, bahwa rakyat di daerah memiliki hak untuk berpartisipasi dalam proses pembahasan rancangan Perda. Hal ini juga menyadarkan kepada kedua lembaga pembantuk Perda tersebut untuk bersikap terbuka dengan memberikan saluran dan tempat untuk rakyat di daerah dalam proses pembahasan rancangan tersebut.

Tanpa komitmen yang nyata untuk melaksanakan (untuk bersikap terbuka) dari kedua lembaga pemenbentuk Perda tersebut substansi dari sebuah demokrasi patut dipertanyakan. Karena demokrasi perwakilan yang dipraktekkan sudah lama dirasakan tidak memadahi. ${ }^{6}$

Peraturan daerah sebagai pedoman dan dasar dalam penyelenggaraan urusan pemerintahan daerah di dalam menetapkannya senantiasa tidak bisa dilepaskan dengan rakyat di daerah. Penyerahan kewenangan pemerintahan kepada daerah pada hakekatnya adalah kepada rakyat di daerah. Konsep daerah (sering disebut dengan daerah otonom) di dalamnya mengandung konsep sosiologis, politis serta konsep kewilayahan. Konsep daerah ini dapat ditemukan dalam undang-undang pemerintahan daerah, dimana daerah diberi batasan sebagai kesatuan masyarakat hukum yang mempunyai batas-batas wilayah yang berwenang mengatur dan mengurus urusan pemerintahan dan kepentingan masyarakat setempat menurut prakarsa sendiri berdasarkan aspirasi masyarakat dalam sistem Negara kesatuan Republik Indonesia. ${ }^{7}$

Berdasarkan uraian tersebut, hakekat dari daerah otonom adalah masyarakat daerah yang bersangkutan, dan apabila berkaitan dengan masyarakat maka kunci atau intinya adalah keterlibatan masyarakat/ partisipasi masyarakat. Dalam konteks ini yang paling urgen adalah pada penyusunan kebijakan dan implementasinya dalam bentuk peraturan daerah.

Walaupun dalam UU No. 10/2004 dan UU No. 32/2004 serta Peraturan Menteri dalam Negeri memeberikan sebuah tuntunan uapaya pelibatan publik dalam proses penyusunan peraturan daerah dari proses inisiasi hingga menagasal sampai pada pengesahannya, wacana atas tidak

${ }^{6}$ PM Hadjon, "Keterbukaan Pemerintahan dan Tanggung Gugat Pemerintahan", Makalah, disampaikan pada Seminar Hukum Nasional Ke- VII dengan Tema Reformasi Hukum Menuju Masyarakat Madani. Diselenggarakan oleh Badan Pembinaan Hukum Nasional - Departemen Kehakiman RI, Jakarta 12 - 15 Oktober 1999, hlm. 5

${ }^{7}$ Pasal 1 angka 6 UU No. 32/2004. 
akomodatif dan tertutupnya ruang partisipasi masyarakat dalam penyusunan kebijakan masih mengemukan hingga sekarang. Hal yang nyata adalah implikasi dari hal ini adalah banyaknya peraturan daerah yang tidak dapat diinternalisasi masyarakat sebagai sebuah kesadaran dalam menaati norma hukum. Untuk itu perlu ada sebuah terobosan dan solusi yang dapat memastikan ruang partisipasi masyarakat dalam penyusunan perda. Terobosan ini tidak hanya berangkat dari masyarakat tetapi harapannya menjadi komitmen pemerintah daerah sebagai aktor utama penyusunan kebijakan.

Tulisan ini akan mengkaji peluang partisipasi masyarakat dalam proses legislasi atau penyusunan peraturan daerah melalui implementasi metode Regulatory Impact Assesment (RIA) sebagai sebuah metode yang terlembagakan dalam pemerintahan daerah. Proses pembahasan dan penentuan peraturan daerah secara teoritis dapat dilakukan dari dua jalur, yaitu jalur lembaga perwakilan daerah dan pemerintah daerah (kepala daerah). Karena kedua lembaga tersebut penentuannya dilakukan secara langsung oleh rakyat di daerah, maka secara politis rakyat memiliki hak untuk berpartisipasi. Pemilihan secara langsung oleh rakyat terhadap anggota DPRD dan kepala daerah, tentunya juga membawa konsekuensi dimana rakyat juga memiliki hak untuk melakukan kontrol dan menarik kepercayaan (public untrust) jika kedua lembaga tersebut tidak dapat diterima oleh publik. Pada sisi lain, kedua lembaga itu juga berkewajiban untuk menciptakan keterbukaan dalam penyelenggaraan pemerintahan sebagai prinsip dasar dalam pemerintahan yang demokratis.

\section{Definisi dan Praktek Partisipasi}

Kecenderungan praktik pemerintahan di akhir milenium kedua menunjukkan kuatnya semangat untuk menjalankan kepemerintahan yang baik (good Governance). Kecenderungan ini karena semakin derasnya dorongan nilai universal yang menyangkut demokrasi, transparansi, dan penghormatan terhadap hak azasi manusia termasuk hak memperoleh informasi yang benar. Praktik kepemerintahan yang baik mensyaratkan bahwa pengelolaan dan keputusan manajemen publik harus di lakukan secara terbuka dengan ruang partisipasi sebesar-besarnya bagi masyarakat yang terkena dampaknya. Konsekuensi dari transparansi pemerintahan adalah terjaminnya akses masyarakat dalam berpartisipasi, utamanya dalam proses pengambilan keputusan. 
Namun apakah makna partisipasi sudah dipahami dengan benar. Tentu tidak. Pada jaman Orde Baru partisipasi lebih diartikan sebagai kerelaan masyarakat mengorbankan harta benda, waktu dan tenaga untuk program pemerintah. Sumbangan uang atau sebidang tanah dari masyarakat untuksuatu proyek jalan desa, misalnya, Diartikan sebagai partisipasi masyarakat. Partisipasi dalam semangat demokrasi bukan lagi semata-mata pengorbanan, tetapi harus dilihat dalam sudut pandang yang luas. Partisipasi seharusnya dipahami sebagai keikutsertaan masyarakat dalam proses manajemen publik yang mencakup: perencanaan, pengambilan keputusan, pelaksanaan, pemantauan, dan evaluasi.

Perbincangan mengenai partisipasi masyarakat bukanlah sesuatu yang baru. Wacana mengenai pentingnya partisipasi masyarakat sejak era Orde Baru sudah didengungkan. Namun dalam realitanya hal itu "lebih baik kabar dari pada rupa" karena dalam pelaksanaannya jauh dari harapan. Dengung partisipasi terdengar lebih "nyaring", ketika kebijakan otonomi daerah direalisasikan UU No. 22 tahun 2002 tentang Pemerintahan Daerah yang sekarang dieprbarui dengan UU No. 32 tahun 2004. Harapan akan meningkatnya partisipasi publik dalam pengambilan kebijakan publik makin besar, karena melalui kebijakan otonomi daerah ini jarak antara pembuatan kebijakan dengan warga masyarakat semakin dekat. ${ }^{8}$

Sudah menjadi pengetahuan umum bahwa masyarakat adalah stakeholders utama kebijakan publik disamping pemerintah daerah dan DPRD. Partisipasi masyarakat juga dianggap penting dalam pembuatan kebijakan, karena warga masyarakat-lah yang mengetahui dan merasakan kebutuhan dan kenyataannya. Hal ini merupakan dasar sosiologis yang penting dalam penyusunan kebijakan publik, disamping dasar yuridis dan filosofis.

Asumsi yang dibangun adalah bahwa kebijakan publik merupakan upaya untuk menanggulangi masalah publik, maka sepatutnya kebijakan itu berorientasi pada kepentingan publik. Konsekuensi lebih lanjut, masalah dan alternatif solusi atas persoalan yang ingin diselesaikan jjuga diharapkan juga berasal dari publik, bukan berdasarkan anggapan dan asumsi yang dibangun oleh para pejabat pembuat kebijakan. Dengan bersandar pada kondisi riel di masyarakat, kebijakan yang dibuat akan dapat diterima secara wajar dan memiliki daya berlaku efektif.

${ }^{8}$ Sad Dian Utomo, "Partisipasi Masyarakat dalam Pembuatan Kebijakan", dalam Lutfi Mustofa (penyelaras), Otonomi Daerah: Evaluasi dan Proyeksi, Yayasan Harkat Bangsa dan Partnsership for Governance Reform in Indonesia, Jakarta, 2003, hlm 267. 
Jika dirinci lebih lanjut, setidaknya terdapat tiga manfaat partisipasi publik dalam pembuatan kebijakan, yaitu: ${ }^{9}$

\section{Terciptanya kebijakan publik yang lebih baik.}

Partisipasi publik akan memberikan landasan yang lebih baik untuk pembuatan kebijakan dan memastikan adanya implementasi yang lebih efektif karena masyarakat mengetahui dan terlibat aktif dalam perumusannya.

\section{Menigkatnya kepercayaan publik terhadap eksekutif dan legislatif}

Pelibatan masyarakat dalam pembuatan kebijakan memberikan kesempatan kepada warga untuk mengetahui rencana pemerintah, kesempatan untuk didengar pendapatnya dan memberikan input dalam pembuatan kebijakan. Semua itumemungkinkan adanya penerimaan yang lebih luas terhadap hasil kebijakan dan menunjukkan keterbukaan pemerintah. Implikasinya adalah legislatif dan eksekutif lebih dapat dipercaya, sehingga legitimasi publik semakin meningkat.

\section{Efisiensi sumber daya}

Karena tingkat penerimaan masyarakat lebih tingi, maka sumber daya yang tadinya digunakan untuk sosialisasi dan pengawasan implementasi dalam rangka mengantisipasi penolakan publik, dapat lebih dihemat dan digunakan untuk hal lain yang lebih strategis, misalnya dalam meningkatkan pelayanan publik.

Upaya pelibatan masyarakat dalam pembuatan kebijakan memang dilakukan oleh legislatif melalui public hearing. Namun hal ini tidak mencukupi. Peserta hearing biasanya dilihat dari faktor keahlian dan bukan mereka yang mengalami langsung dampak dari kebijakan yang sedang disusun tersebut. Selain itu, tindaklanjut dari hearing tersebut juga masih dipertanyakan, karena tidak ada sistem yang menjamin diterimanya aspirasi rakyat tersebut.

\section{Kebijakan Partisipatif}

Paling tidak terdapat dua model kebijakan yang kiranya konstruktif untuk mengkerangkai pemikiran tentang mekanisme pembuatan

\footnotetext{
${ }^{9} \mathrm{Ibid}, \mathrm{hlm} 268$.
} 
kebijakan publik: yakni model 'kebijakan sebagai perjuangan kepentingan masyrakat' dan model 'kebijakan sebagai proses social marketing'. Keduanya akan dipaparkan sebagai berikut. ${ }^{10}$

\section{a. Kebijakan sebagai perjuangan kepentingan masyrakat.}

Kalau kita tidak berfikir birokratis-yuridis semata, maka proses kebijakan publik tidak harus mengandalkan peran aktif pejabat negara. Ini tidak berarti bahwa negara dikesampingkan dalam proses kebijakan. Bahwa dalam negara ada aktor-aktor yang telibat dalam proses penentuan isi kebijakan, itu tidak dibantah. Hanya saja, titik strategis yang diutamakan dalam memahami proses kebijakan adalah proses politik, bukan proses birokratis. Proses politik yang dimaksudkan adalah proses politik yang digerakkan oleh partisipasi politik masyarakat dalam pengambilan kebijakan publik.

Proses kebijakan, dari kacamata penganjur gagasan ini (misalnya teori sistem), dilihat sebagai proses tuntut-menutut dan dukung-mendukung gagasan kebijakan yang harus difikirkan oleh pejabat pemerintah. Dalam konteks ini, peran pengambil kebijakan keputusan dibayangkan hanya sebatas merespon tuntutan dan dukungan yang disampaikan oleh masyarakat. Dalam proses ini institusi-institusi politik yang ada telah menyediakan arena untuk mengagregasikan berbagai kepentingan yang ada dalam masyarakat. Penentuan daftar skala prioritas, tawar-menawar antara berbagai fihak yang terkait bisa dilakukan secara mandiri oleh masyarakat dengan mengacu pada aturan main dan prosedur yang ada.

Adanya kapasitas kelembagaan inilah yang memungkinkan berbagai benturan berbagai kepentingan masyarakat bisa diatasi. Masyarakat sendiri menyadari betapa pentingnya menghormati prosedur-prosedur yang telah ada untuk memungkinkan proses kebijakan publik bisa berlangsung dan mengenai sasaran. Dalam situasi yang demikian ini maka mereka yang tidak sepakat dengan isi kebijakan akan bersedia mematuhi keputusan kebijakan. Ini berarti berjalannya kebijakan tidak lagi harus mengandalkan legalitas keputusan pemerintah, melainkan justru legitimasi proses pengambilan kebijakan.

\footnotetext{
${ }^{10}$ Purwo Santoso, makalah pada Workshop Multistakeholder Membangun Mekanisme Pembuatan Kebijakan Daerah yang Partisipatif yang diselenggarakan oleh Jogjakarta Transparancy, bekerja sama dengan Independent Legal Aid Institute (ILAI) dan Partnership for Governance Reform in Indonesia, Yogyakarta : 20 Januari 2003.
} 
Bahwa kebijakan akan merugikan fihak-fihak tertentu dan menguntungkan fihak-fihak lain, dari kacamata society centric ini dianggap tidak bermasalah. Keputusan pemerintah yang tidak memuaskan akan menggerakkan fihak yang tidak puas ini untuk memperjuangkan kepentingannya. Dengan demikian maka proses kebijakan akan terusmemerus mengalir dalam bentuk tuntutan/dukungan masyarakat yang senantiasa direspon secara mekanistik poleh pejabat para negara.

\section{b. Kebijakan sebagai proses social marketing.}

Model yang kedua sebetulnya disarikan dari pengalaman negaranegara industri maju yang telah lama mengembangkan liberalisme sebagai pilar pemerintahannya. Kesadaran akan hak-hak politik masyarakat telah menjadi sandaran bagi tegaknya hukum, dan proses kebijakan memang bisa disederhanakan sebagai proses merespon tuntutan dan dukungan masyarakat. Kalau model ini mau dijadikan basis (acuan praktis) untuk pengelolaan proses kebijakan, maka prasyarat-prasyarat bagiberjalannya model ini harus dipenuhi. Prasyarat tersebut adalah bahwa proses kebijakan berlangsung dengan dukungan kapasitas kelembagaan yang memadai. Proses artikulasi dan agregasi kepentingan, misalnya, dijalankan oleh partai-partai politik. Artinya, model kedua mensyaratkan kuatnya basis politik kepartaian. Prasyarat semacam ini tampaknya tidak dengan mudah bisa dipenuhi oleh masyarakat Indonesia saat ini. Ini juga berarti bahwa, peran aktif dan pro-aktif pemerintah, memang tidak bisa dihindarkan. Sehubungan dengan hal itu, maka model pertama bisa dijadikan acuan dengan sejumlah modofikasi.

Alternatif model yang mengkombinasikan kedua model tersebut di atas ditawarkan oleh J.A. Altman. Dia menyebutnya sebagai model social marketing, dimana pejabat negara dituntut untuk aktif dalam proses kebijakan, namun keaktifan tersebut tidak menghilangkan mereduksi arti penting kesepakatan (consent) dari masyarakat.

\section{Kebijakan Pembentukan Peraturan Perundang-Undangan}

Setelah terjadinya perubahan UUD ' 45 , maka kebijakan pokok mengenai pembentukan dan pembaruan peraturan perundang-undangan juga mengalami perubahan mendasar. Pada tahun 2004 dibentuk satu undang-undang baru yang mengatur menganhi seluk beluk pembentukan peraturan perundang-undangan Republik Indonesia. Undang-undang 
(UU) yang dimaksud adalah Undang-undang Nomor 10 Tahun 2004 tentang Pembentukan Peraturan Perundang-undangan. ${ }^{11}$ Dengan berlakunya UU ini, maka semua peraturan perundangan yan mengatur tentang pembentukan peraturan perundang-undangan yang ada dinyatakan tidak berlaku lagi.

Sesuai dengan ketentuan pasal 5, bahwa pembentukan peraturan perundang-undangan harus didasarkan pada asas pembentukan peraturan perundang-undangan yang baik. ${ }^{12}$ Asas-asas tersebut dapat dibedakan dalam dua kategori. ${ }^{13}$ Pertama adalah asas yang di tentukan pada pasal 5, yang disebut dengan kategori asas formil, karena berkenaan dengan format, sifat, wadah, kelembagaan yang berperan, teknis perumusan dan sebagainya. Sedangkan yang kedua adalah 10 asas yag ditentukan pada pasal 6 ayat (1) yang kemudian dikategorikan sebagai asas materiel, yaitu asas yang harus terkandung dalam materi muatan setiap peraturan perundang-undangan.

Ketujuh asas formil yang ditentukan dalam pasal 5 Undang-Undang Nomor 10 Tahun 2004 meliputi asas-asas: (a) kejelasan tujuan; (b) kelembagaan atau organ pembentuk yang tepat; (c) kesesuaian antara jenis dan materi muatan; (d) dapat dilaksanakan; (e) kedayagunaan dan kehasilgunaan; (f) kejelasan rumusan; dan (g) keterbukaan.

Sedangkan kesepuluh asas yang bersifat materiel seperti ditentukan pada pasal 6 ayat (1) adalah berupa: pengayoman; kemanusiaan; kebangsaan; kekeluargaan; kenusantaraan; bhineka tunggal ika; keadilan; kesamaan kedudukan dalam hukum dan pemerintahan; keterlibatan dan kepastian hukum, dan/atau keseimbangan, keserasian, dan keselarasan. ${ }^{14}$

\section{Bentuk Peraturan Perundang-Undangan}

Dalam Undang-undang Nomor 10 Tahun 2004 tentang Pembentukan Peraturan Perundang-Undangan Lembaran Negara Tahun 2004 Nomor 53 pasal 7 (1) Jenis peraturan dan hierarki Peraturan Perundang-undangan adalah sebagai berikut : a. Undang-Undang Dasar Republik Indonesia Tahun 1945; b. Undang-Undang/Peraturan Pemerintah Penganti

\footnotetext{
${ }^{11}$ Jimly Asshiddiqie, Pokok-Pokok Hukum Tatanegara Pasca Reformasi, Jakarta, PT. Buana Ilmu Populer, 2007, hlm 266.

${ }^{12}$ Pasal 5, UU Nomor 10 Tahun 2004.

${ }^{13}$ Jimly Asshiddiqie, Op.Cit., hlm 269.

${ }^{14}$ Pasal 6, UU Nomor 10 Tahun 2004.
} 
Undang-Undang; c. Peraturan Pemerintah; d. Peraturan Presiden; e. Peraturan Daerah.

Berdasarkan ketentuan pasal tersebut, Peraturan Daerah merupakan bentuk hukum terendah dari hierarki bentuk peraturan perundangan di Indonesia. Implikasi dari hal tersebut, sebuah Peraturan Daerah (Perda) akan sangat jelas tentang kedudukan, lembaga pembentuk, isi serta mekanisme pengujiannya.

Pasal 7 ayat (2) Peraturan Daerah sebagaimana dimaksud ayat (1) huruf e meliputi: a. Peraturan Daerah Propinsi dibuat oleh Dewan Perwakilan Rakyat Daerah propinsi bersama dengan Gubernur; b. Peraturan Daerah Kabupaten/Kota dibuat oleh Dewan Perwakilan Rakyat Daerah kabupaten/kota bersama bupati/walikota; c. Peraturan Desa/ peraturan yang setingkat, dibuat oleh Badan Perwakilan Desa atau nama lainnya bersama dengan Kepala Desa atau nama lainnya.

Selain Peraturan Daerah, produk hukum daerah yang lain adalah peraturan kepala daerah dan atau keputusan kepala daerah. Ke dua produk hukum daerah ini merupakan peraturan pelaksanaan Peraturan Daerah, dimana dari segi materi dilarang bertentangan dengan kepentingan umum, Peraturan Daerah dan peraturan perundangundangan yang lebih tinggi. ${ }^{15}$

Sesuai dengan lingkup tema yang dikaji, maka bentuk produk hukum daerah yang dimaksud dalam tulisan ini adalah Peraturan Daerah, yaitu Peraturan Daerah Kabupaten/Kota ataupun provinsi.

\section{Regulatory Impact Assessment: Sebuah Tawaran Konsep}

RIA (Regulatory Impact Assessment) adalah sebuah metode yang secara sistematis dan konsisten mengkaji pengaruh yang ditimbulkan oleh tindakan pemerintah, mengkomunikasikan informasi kepada para pengambil keputusan. ${ }^{16}$ RIA pada dasarnya digunakan untuk menilai regulasi dalam hal: relevansi antara kebutuhan masyarakat dan sasaran kebijakan, kebutuhan terhadap intervensi pemerintah, efisiensi antara input dan output, efektifitas antara sasaran kebijakan dan hasil, keberlanjutan antara kebutuhan masyarakat dan hasil sebelum diterapkannya atau dirubahnya suatu regulasi. Dengan menggunakan

\footnotetext{
${ }^{15}$ Pasal 146 UU No.32/2004.

${ }^{16}$ Asian Development Bank, Regulatory Impact Assessment (RIA) Guide Book, Jakarta: 2002, hlm. 7.
} 
metode RIA diharapkan regulasi yang ada semakin baik, mendukung bagi iklim usaha khususnya bagi regulasi terkait usaha dan menciptakan keserasian regulasi secara umum yang pada akhirnya memberikan dampak pada peningkatan kesejahteraan masyarakat. ${ }^{17}$

Tuntutan pokok dari RIA adalah sebagai berikut: (1) memberikan alasan perlunya intervensi pemerintah; (2) memberikan alasan regulasi adalah alternatif yang terbaik; (3) memberikan alasan bahwa regulasi memaksimumkan manfaat sosial bersih dengan biaya minimum; (4) mendemonstrasikan bahwa konsultasi yang cukup telah dilakukan; (5) menunjukkan bahwa mekanisme kepatuhan dan implementasi yang sesuai telah ditetapkan. ${ }^{18}$ Secara runtut dapat dilihat pada bagan berikut:
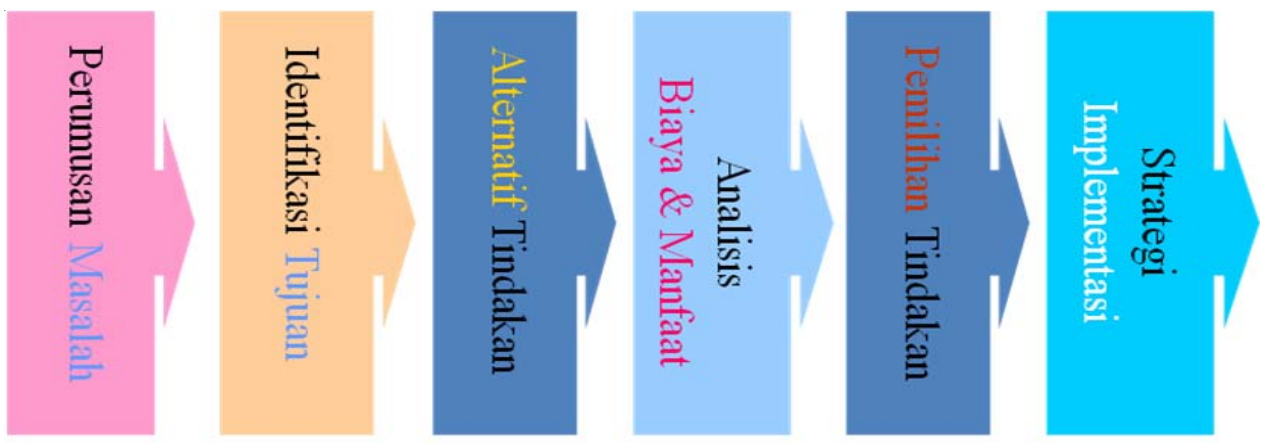

\section{Konsultasi Publik}

Penjelasan singkat mengenai tahapan metode RIA (Regulatory Impact Assessement) yang dapat membantu pengambil kebijakan dalam merumuskan kebijakan dan melakukan review atas kebijakan yang ada. ${ }^{19}$

\section{Tahap 1: Perumusan Masalah.}

Dalam hampir semua kasus, pemerintah menerbitkan kebijakan karena ingin menyelesaikan suatu masalah. Dalam tahap ini analis kebijakan antara lain ingin mengetahui: Apakah dalam mengeluarkan kebijakan, pemerintah telah memahami masalah yang sebenarnya? Apakah masalah yang ingin diselesaikan benar-benar ada? Atau hanya gejalanya? Apakah

\footnotetext{
${ }^{17}$ Nasokah, Reformasi Regulasi menuju Penciptaan Iklim Usaha yang Kondusif, Opini, Suara Merdeka, 16 April, 2006.

${ }^{18}$ Ibid.

${ }^{19}$ Asian Development Bank, Op. Cit., hlm. 23-40.
} 
tidak terdapat masalah yang lebih mendasar? Apakah akar penyebab timbulnya masalah? Dan bagaimana persepsi para stakeholders (fihak yang terkait) terhadap masalah tersebut?

\section{Tahap 2: Identifikasi tujuan (sasaran) Kebijakan.}

Dalam tahap ini analis kebijakan berusaha mengetahui sasaran yang ingin dicapai pemerintah melalui penerbitan kebijakan. Dalam beberapa kasus, sasaran suatu kebijakan tentu saja adalah untuk menyelesaikan 'masalah' yang sudah diidentifikasi pada tahap tersebut di atas. Namun dalam banyak kasus, suatu 'masalah' mungkin cukup pelik dan rumit sehingga tidak bisa diselesaikan hanya dengan satu tindakan (kebijakan) saja. Dalam keadaan demikian, maka kebijakan pemerintah biasanya dibuat memang hanya ditujukan untuk mengatasi sebagian dari masalah yang dihadapi. Oleh karena itu, analis kebijakan harus mengidentifkasikan dengan jelas sasaran yang ingin dicapai oleh kebijakan tersebut.

Pertanyaan yang perlu dicarikan jawabannya, antara lain, Apakah tujuan (sasaran) pemerintah dalam menerbitkan kebijakan? Apakah sasaran kebijakan tersebut untuk menyelesaikan sebagian dari, atau keseluruhan, permasalahan yang dihadapi? (problem biasanya cukup kompleks, sehingga diperlukan beberapa kebijakan untuk menyelesaikan problem secara menyeluruh). Selain itu, analis juga perlu melihat apakah pemerintah memiliki kewenangan mengeluarkan kebijakan tersebut dan apakah kebijakan tersebut konsisten dengan undang-undang dan peraturan lainnya.

\section{Tahap 3: Identifikasi Alternatif (opsi) Penyelesaian Masalah.}

Pada tahap ini, analis kebijakan mereview pengembangan alternatif tindakan (opsi) yang dapat digunakan untuk mencapai tujuan dan sasaran yang telah diidentifikasi. Fokus review dalam tahap ini adalah melihat apakah pemerintah telah mempertimbangkan seluruh opsi (alternatif tindakan) yang tersedia.

Analis kebijakan juga harus memperhatikan apakah terdapat cara (alternatif tindakan) lain yang lebih baik dan lebih jelas, yang dapat digunakan pemerintah untuk mencapai tujuannya? Bagaimana dengan alternatif tidak melakukan apa-apa (do nothing)? Dengan melihat alternatif penyelesaian masalah lainnya, kita dapat membandingkan dan mempertimbangkan alternatif manakah yang lebih baik dalam mencapai hasil yang diinginkan. 


\section{Tahap 4: Analisis manfaat dan biaya.}

Dalam tahap ini, analis kebijakan melakukan assessment atas manfaat dan biaya (keuntungan dan kerugian) untuk setiap opsi atau alternatif tindakan yang penting, dilihat dari sudut pandang pemerintah, masyarakat, konsumen, pelaku usaha, dan ekonomi secara keseluruhan.

\section{Tahap 5: Komunikasi (konsultasi) dengan stakeholders.}

Kebijakan yang baik adalah kebijakan yang secara terus-menerus dikomunikasikan kepada para stakeholders, terutama pelaksana yang menjalankan kebijakan di lapangan. Konsultasi ini harus dilakukan dari mulai tahap awal perumusan kebijakan sampai dengan tahap implementasi dan monitoring pelaksanaan kebijakan. Dalam model kita, konsultasi sudah mulai dilakukan dalam tahap identifikasi masalah. Konsultasi pada tahap ini bertujuan untuk memastikan bahwa pemerintah menangani masalah yang tepat, dan bahwa persepsi pemerintah terhadap masalah yang dihadapi sama dengan persepsi masyarakat, pelaku usaha, maupun stakeholders lainnya.

Konsultasi pada tahap pengembangan alternatif terutama bertujuan untuk mendapatkan masukkan mengenai opsi yang dapat dipilih, dan untuk menguji apakah opsi tertentu dapat dijalankan secara layak (workable). Dalam tahap analisis costs/benefit, konsultasi terutama bertujuan untuk mendapatkan masukkan mengenai biaya (kerugian atau kesulitan) dan manfaat (keuntungan) dari setiap opsi, dan untuk mendapatkan konfirmasi apakah biaya/manfaat yang diharapkan benar-benar terwujud dalam prakteknya.

\section{Tahap 6: Penentuan opsi (alternatif kebijakan) terbaik.}

Setelah mempertimbangkan berbagai kemungkinan opsi tindakan, dan setelah membandingkan berbagai biaya dan manfaat dari opsi tersebut, maka tahap selanjutnya adalah memilih opsi tindakan yang terbaik untuk mencapai sasaran dan menyelesaikan masalah yang telah dirumuskan sebelumnya. Fungsi analis dalam tahap ini adalah memastikan bahwa pemerintah telah membandingkan semua costs/benefits dan memilih opsi yang paling efisien dan efektif.

\section{Tahap 7: Perumusan strategi implementasi kebijakan.}

Setelah opsi dipilih, tahap selanjutnya adalah merumuskan startegi untuk mengimplementasikan kebijakan di lapangan. Strategi implementasi 
mencakup penatausahaan (administrasi) kebijakan, sosialisasi kebijakan, dan monitoring pelaksanaan kebijakan.

\section{Penutup}

RIA (Regulatory Impact Assessment) adalah sebuah metode untuk mengevaluasi kebijakan, sebuah metode yang bertujuan menilai secara sistematis pengaruh negatif dan positif regulasi yang sedang diusulkan atau yang sedang berjalan. Namun demikian, Metode RIA dapat digunakan dalam dua hal: Pertama, sebuah filter atas usulan peraturan daerah. Ide dan gagasan pengusulan peraturan daerah harus dapat diuji apakah memang masalah yang ingin diselesaikan harus menggunakan peraturan daerah atau dapat diselesaikan dengan instumen lainnya. Apakah pula masalah yang ingin diselesaikan adalah masalah publik. Kedua, melakukan analisa dan review terhadap dampak sebuah peraturan daerah. Apakah memang rumusan kebijakan dapat menyelesaikan masalah yang awalnya ingin diselesaikan dan sampai sejauh mana dampak yang ditimbulkannya.

Untuk memastikan implementasi metode ini sebagai metode perumusan kebijakan, terdapat tiga tawaran yang coba penulis sampaikan: (1) RIA dipahami sebuah metode ansich, oleh karena RIA hanya akan menuntun cara berfikir pembuat peraturan daerah tanpa merubah mekanisme dan kelembagaan yang ada; (2) RIA dicangkokkan dalam kelembagaan penyusunan perda selama ini. Baik di level eksekutif maupun legislatif; (3) RIA dilembagakan secara mandiri sebagai quality control atas segala peraturan daerah, baik yang baru diusulkan maupun atas peraturan daerah yang telah ada.

Diakui memang terdapat banyak metode yang bisa kita gunakan dalam proses pembuatan dan evaluasi regulasi. RIA merupakan salah satu metode saja untuk menganalisa apakah regulasi yang ada sudah dirumuskan secara maksimal dengan melibatkan stakeholder, karena regulasi yang baik adalah regulasi yang dapat memberikan manfaat yang besar bagi banyak pihak dan bukan sebaliknya justru akan menghambat bagi perkembangan usaha dan peningkatan kesejahteraan semua pihak. Namun demikian, menurut hemat penulis jika metode ini konsisten dilaksanakan dan dijalankan serta diinternalisasi oleh penyusun peraturan daerah akan dapat memastikan proses yang partisipatif dan juga memastikan substansi yang sesuai dengan tujuan dibentuknya perda tersebut. 


\section{Daftar Pustaka}

Agus Dwijanto et. al, Kinerja Tata Pemerintahan di Indonesia, Yogyakarta: Pusat Studi Kependudukan dan Kebijakan Universitas Gajah Mada (PSKK UGM)-Kemitraan, 2007

Asian Development Bank, Regulatory Impact Assessment (RIA) Guide Book, Jakarta: 2002

Jimly Asshiddiqie, Pokok-Pokok Hukum Tatanegara Pasca Reformasi, Jakarta, PT. Buana Ilmu Populer, 2007

Nasokah, Reformasi Regulasi menuju Penciptaan Iklim Usaha yang Kondusif, Opini, Suara Merdeka, 16 April, 2006.

PM Hadjon, "Keterbukaan Pemerintahan dan Tanggung Gugat Pemerintahan", Makalah, disampaikan pada Seminar Hukum Nasional Ke- VII dengan Tema Reformasi Hukum Menuju Masyarakat Madani. Diselenggarakan oleh Badan Pembinaan Hukum Nasional Departemen Kehakiman RI, Jakarta 12 - 15 Oktober 1999

Purwo Santoso, makalah pada Workshop Multistakeholder Membangun Mekanisme Pembuatan Kebijakan Daerah yang Partisipatif yang diselenggarakan oleh Jogjakarta Transparancy, bekerja sama dengan Independent Legal Aid Institute (ILAI) dan Partnership for Governance Reform in Indonesia, Yogyakarta : 20 Januari 2003.

Word Bak Institute, Perda Review Project, September, 2004, dalam http:// www.justiceforthepoor.or.id.

Undang-Undang Dasar RI 1945.

UU No. 10/2004 tentang pembentukan Peraturan Perundang-undangan. UU No. 32/2004 Tentang Pemerintahan Daerah. 